\title{
PENGEMBANGAN PEMBELAJARAN BERWAWASAN KEWIRAUSAHAAN DI PESANTREN MINORITAS MUSLIM
}

\author{
Ismail Suardi Wekke \\ Sekolah Tinggi Agama Islam Negeri (STAIN) Sorong \\ Jl. Klamono-Sorong, KM. 17, Klablim, Sorong 98417 \\ Email: iswekke@gmail.com Tlp.0813-1554-0777 \\ Dipresentasikan dalam Seminar Internasional Indonesia-Maroko \\ "Islam dan Tantangan Globalisasi; Pengalaman Indonesia-Maroko" \\ Yogyakarta, 14-16 Maret 2014
}

\begin{abstract}
Pesantren (boarding school) in Indonesia educational system prooves a significant contribution. They participate in enhancing teaching and learning and extending the processes of acquiring knowledge with the spirit of Islam. These activities spread out through the nation-wide, include some part of Papua island. Therefore, it is a need to explore the practice of Islamic education, expecially muslim minority. Where the religious based institution will have less culture support and different environment from other majority. A qualitative approach was employed to conduct this research. In-depth inteview and non-participant observation were implemented during data collection. There are four pesantrens were observed, they are Pesantren Nurul Yaqin, Pesantren Roudhotul Khuffadz, Pesantren Minhajut Tholibin, and Pesantren Hidayatullah. All the site are located in Sorong regency. Research findings shows one of the option in elaborating learning process in pesantren to accelerate students' skill is impelementation of entrepeneurship. After school duration, extracurriculer is running to maintain the learning outside classroom. Students still have opportunity to learn not only in the classroom but also they will participate in the real space. The extension of classroom to the field is an effort to relate theoretical attainment to skills development. Those institutions executed this kind of program due to limited time in practice for subject matter on time allocation. Finally, pesantren is not solely the place to learn religion. Management board tried to encourage students in participating the entrpreneurship based various activities to complement students' skills after graduating from the Islamic school.
\end{abstract}

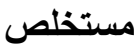

$$
\begin{aligned}
& \text { المعهد فى منهج التعليم أندوننيسيا تفع فى المكان المهم. هم يشتركون فى تتمية التعليم والتعلم ويحرك فى } \\
& \text { تحصيل العلوم مع نية صالحة اللدين الاسلامية. هذه البرنامج يجرى فى الوطن كلها وهناك ايضا فى فافؤ } \\
& \text { الغربية. لذللك، نحتاج ان نبصث العمل فى تربية الاسلامية خصوصسا المسلم القليل. اين تقع المعاهد التى لا } \\
& \text { توجد الثقافة والبيئة المتتوعة من المسلم الكثير. بحث وصفيا نوعيا تطبع حينا جمع المعلومات. الحوار } \\
& \text { و الملاخطة نوعان لتحصيل البيانات. تجدار بع معاهد لتجيد المقابلة وهم المعهد نور اليقين، المعهد روظة } \\
& \text { الخفاظ، المعهد منحج الطالبين، والمعهد هداية الله، كلهم تقع فى دائرة سورنج. البحث نشيران احد من } \\
& \text { البر امج الذى تحاصل في اضافة تعلم الطلاب المعهد وهو المهارة الاجارية بعد حصة الدارسة فى الفصل، } \\
& \text { تجرى البرنامج ليساعد الطلاب ليتعلم خارج الفصل. الطلاب مازل يستطعون ان يتعلمون لو انهم ليس فى } \\
& \text { فصل ولكن عندهم الفرصة ليشترك فى مكان معين. اضافة الفصل فى المبدان احد من الافعال ليتجح العل } \\
& \text { الى كيفيات وتبنى المهار ات. تلك المعاهد يرى هذه البرامج لأن قلة الحصة فى تطبيق الدروس على فرصة }
\end{aligned}
$$




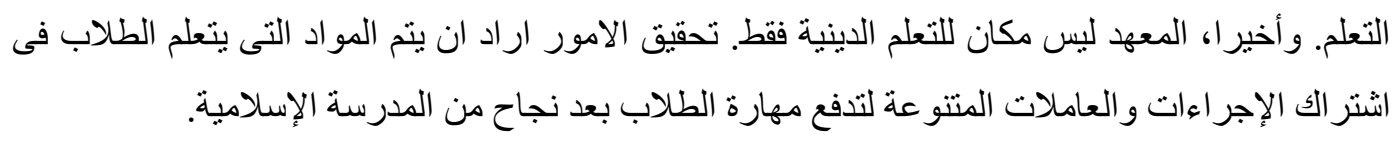

Keywords: muslim minority, pesantren, entrpreneurship.

\section{A. Pendahuluan}

Pendidikan selalu menjadi sebuah pilihan utama bagi masyarakat muslim sebagai sebuah institusi untuk mendukung kapasitas dan juga transformasi pengetahuan. Bahkan dalam suasana perang sekalipun, tetap saja masyarakat Islam berupaya untuk membentuk lembaga pendidikan dengan segala keterbatasan, apalagi jikalau itu dalam suasana damai. Muslim Palestina yang tanahnya dikuasai Israel tetap berusaha menghadirkan lembaga pendidikan yang terprogram, sekaligus mengajarkan pendidikan Islam dan keterampilan berwirausaha. ${ }^{1}$ Padahal, dengan suasana pencaplokan tanah seperti itu tentu kesulitan dan rintangan senantiasa mewarnai kehidupan sehari-hari. Hanya saja, semangat itu tidak pernah putus, justru berusaha menghadirkan sebuah lembaga yang mampu memberikan pelatihan bagi mempersiapkan masa depan anak-anak. Dengan demikian sudah menjadi praktik umum di dunia Islam bahwa pendidikan adalah hal yang utama untuk ditegakkan. Dengan usaha bersama dan dalam keadaan apapun, membentuk sebuah lembaga pendidikan adalah mutlak untuk dilakukan.

Begitu juga dengan umat Islam Papua Barat. Hidup di tengah-tengah komunitas agama lain, tetapi pendidikan menjadi hal yang utama untuk didirikan sebagai sebuah wadah dalam pengembangan kapasitas muslim. Tentu tantangannya akan berbeda jika ini berada di mayoritas muslim. Sebagaimana penelitian yang ada selama ini, hanya lebih banyak menggambarkan dinamika pendidikan Islam di masyarakat muslim yang homogen. Sementara minoritas muslim, memberikan sebuah fenonema yang mungkin saja sama tetapi ada perbedaan yang mencolok. Ada hal-hal yang berhubungan dengan akulturasi ${ }^{2}$,

1 Ayman K. Agbaria dan Muhanad Mustafa, "The Case Of Palestinian Civil Society In Israel: Islam, Civil Society, and Educational Activism", Critical Studies in Education, Vol. 55, No. 1 (2014), hal. 44-57.

${ }^{2}$ A. Jamal dan S. A. Shukor, "Antecedents and Outcomes of Interpersonal Influences and the Role of Acculturation: The Case of Young British-Muslims", Journal of Business Research, Vol. 67, No. 3 (Maret 2014), hal. 237-245. 
multikultural $^{3}$, dan juga identitas ${ }^{4}$. Kesemuanya ini menjadi bagian dari perjumpaan dengan warga lain yang berbeda budaya dan keyakinan. Sehingga akan memberikan sikap dan gaya yang juga diadaptasi oleh warga muslim.

Pendidikan dalam kaitannya dengan ekonomi menjadi sebuah kecenderungan dalam perhatian para peneliti. Penelitian yang dilakukan para sarjana terbagi atas beberapa tema penelitian antara lain dampak ekonomi ${ }^{5}$, pendidikan tinggi ${ }^{6}$, pengembangan kelembagaan ${ }^{7}$, dan pendapatan $^{8}$. Keempat tema tersebut kemudian menjadi pemicu lahirnya penelitian lanjutan untuk memberikan tambahan kajian bagi eksplorasi ilmu pengetahuan. Namun demikian penelitian ekonomi dengan melihat pada sudut pandang pembelajaran kewirausahaan dengan pola yang didasari dari sebuah lembaga keagamaan belum digambarkan secara menyeluruh. Padahal, pembelajaran kewirausahaan juga merupakan bagian dari praktik lembaga pendidikan Islam Indonesia. Dalam praksisnya, lembaga pendidikan tidak dapat berlangsung jikalau tidak melibatkan sisi ekonomis dalam aktivitasnya. Paling tidak, dalam hal pengadaan sarana dan prasarana untuk mendukung proses belajar mengajar.

Dengan demikian, sebuah kepentingan untuk menjalankan penelitian dengan melihat unsur kewirausahaan yang dilaksanakan dalam pendidikan Islam. Selanjutnya, faktor minoritas muslim juga menjadi sebuah bagian yang perlu diungkap dalam pembahasan. Penelitian ini menjadikan variabel wawasan kewirausahaan dan minoritas muslim sebagai dua unsur secara bersamaan yang dijadikan sebagai fokus kajian.

3 M. Maussen, dan R. Grillo, "Regulation of Speech in Multicultural Societies: Introduction", Journal of Ethnic and Migration Studies, Vol. 40, No. 2 (Februari 2014), hal. 174193.

${ }^{4}$ I. Sheikh, A. Mohyuddin, H-R. Chaudry, dan S. Iqbal, "Identity and Self Images in Adoscence a Case Study of Bumburet valley in District Chitral Pakistan", World Applied Sciences Journal, Vol. 29, No. 1 (2014), hal. 96-105.

5 Fernanda Esteva, "The impact of Conditional Cash Transfer on Public Education Expenditures: A Political Economy Approach", European Journal of Political Economy, Vol. 32 (Desember 2013), hal. 268-284.

${ }^{6}$ Nathalie Huber, "Science and Higher Education in the Context of Economy and Media", Kolner Zeitschrift Fur Soziologie Und Sozialpsychologie, Vol. 65, No. 4 (Desember 2013), hal. 734-737.

${ }^{7}$ E. I. Medvedeva, "The Rsetructuring of Education Under Conditions of the Innovative Development of the Economy", Russian Education and Society, Vol. 55, No. 11 (November 2013), hal. 84-93.

8 Stuart Greene, "Mapping Low-Income African American Parents' Roles in Their Children's Education in a Changing Political Economy", Teachers College Board, Vol. 115, No. 10 (Oktober 2013). 


\section{B. Landasan Teoritis}

Lembaga pendidikan senantiasa berusaha untuk menyerap keadaan mutakhir dari perkembangan lingkungan. Demikian pula dengan pengelolaan pendidikan yang tidak stagnan tetapi dinamis menyesuaikan dengan kondisi yang ada. Dengan dasar ini, maka setiap lembaga pendidikan mengalami perkembangan yang tidak sama. Dimana keberadaan lingkungan masing-masing memberikan kontribusi dalam pertumbuhannya. Dengan akses pendidikan yang lebih baik, akan memberikan kemampuan dan keterampilan kepada lulusan lembaga pendidikan. Mereka kemudian akan mendapatkan keutungan dalam hal kualifikasi untuk menempati posisi tertentu dalam bursa tenaga kerja. Tidak saja itu, mereka bahkan mampu menciptakan lapangan kerja bagi orang lain. ${ }^{9}$ sehingga pendidikan menjadi sebuah solusi bagi masyarakat.

Selanjutnya, manajemen pendidikan senantiasa melibatkan orang tua untuk turut menjadi pemangku kebijakan dalam penetapan urusan di sekolah. Untuk itu, orang tua melalui Komite Sekolah berkesempatan memberikan pandangan sekaligus turut mengawasi jalannya proses pendidikan. Saran dan juga pendapat yang disampaikan akan menjadi bagian dari implementasi dan kinerja pengelolaan sehari-hari. Pada orang tualah yang menjadi pendukung utama lembaga. Mereka setiap bulan mengirim pembiayaan bagi anaknya masingmasing. Sebuah penelitian yang dilaksanakan Estevan menunjukkan peningkatan ekonomi suatu daerah dapat terbangun karena adanya pengeluaran tetap yang dibayarkan setiap bulan oleh para pelajar. ${ }^{10}$ Maka, menjadi sebuah pola manajemen yang tepat jika orang tua dilibatkan untuk menjadi penentu kebijakan. Pada tangan merekalah sebuah keputusan dapat diambil karena mereka juga yang menjadi pilar utama pembiayaan.

Keberlanjutan merupakan sebuah isu yang menjadi perhatian pengelola pendidikan. Dimana pendirian sebuah lembaga kemudian tidak berhenti hanya sampai pada operasional saja. Tetapi hal utama yang diinginkan bagaimana

${ }^{9}$ Eliane El Badaoui dan Theresa Rebiere, "Education, Informality, and Efficiency: A Matching Model for a Developing Economy", Revue d Economie Politique, Vol. 123, No. 3 (2013), hal. 423-441.

${ }^{10}$ Fernanda Estevan, "The Impact of Conditional Cash Transfer on Public Education Expenditures: A Political Economy Approach", European Journal of Political Economy, Vol. 32 (Desember 2013), hal. 268-284. 
lembaga yang sudah didirikan mampu memberikan kontribusi bagi masyarakat sekitarnya. Untuk itu, manajemen dan sinergitas kelembagaan dengan memperhatikan lingkungan dan kebutuhan wilayah sebuah pandangan yang juga diperhatikan lembaga. Sebuah komponen yang kompleks antara faktor-faktor sosial, ekonomi dan ekologi. Manring menjelaskan interaksi antara manusia dengan sistem yang terbentuk alam, dapat saja menjadi sebuah faktor untuk mengintegrasikan seluruh rangkaian yang ada. ${ }^{11}$ Rekomendasi ini memungkinkan untuk membentuk sebuah alat-alat kelengkapan lembaga dalam rangka membantu pertumbuhan ekonomi kawasan.

Sebuah lembaga seperti pesantren dapat berlangsung dengan baik sesuai dengan harapan sebagaimana pendirian karena adanya kepercayaan yang dibangun dengan sebuah kerja keras. Bahkan di penjara sekalipun, bagi orangorang yang terdakwa, sementara menjalani hukuman. Ketika mereka sudah berada dalam lingkungan yang memberikan kepercayaan, maka para narapidana dapat saja berbuat sesuai dengan tuntutan yang diberikan. Dengan satu persyaratan utama yaitu bagaimana mengintegrasikan keinginan lembaga dengan senantiasa memperhatikan masalah-masalah yang muncul sehingga dapat diatasi sedini mungkin. ${ }^{12}$ Apalagi pendidikan pesantren yang sejak awal pendiriannya dibangun dengan modal kepercayaan dari masyarakat. Maka, potensi pengembangan dapat saja dilakukan dengan pelbagai upaya, sehingga dapat mengantarkan peserta didik untuk menguasai pelbagai keterampilan. Sinergitas, kolaborasi, penyelesaian masalah, dan pengembangan berkelanjutan dilakukan pesantren untuk tetap menjadi bagian dari pendidikan muslim.

Keberadaan pesantren yang berada di pedesaan menjadi sebuah potensi untuk menjadi bagian dari pengembangan pedesaan itu sendiri. Para pengasuh pesantren menjadi pihak yang sangat memahami kondisi pedesaan yang menjadi lingkungan tumbuh kembangnya pesantren. Selanjutnya dengan pemahaman ini akan menjadi sebuah kesempatan untuk mengidentifikasi potensi yang menjadi bagian dari pendidikan yang dapat disinergikan dengan kemampuan pendidikan

11 Susan L. Manring, "The Role of Universities in Developing Interdisciplinary Action Research Collaborations to Understand and Manage Resilient Social-Ecological Systems", Journal of Cleaner Production, Vol. 64 (Februari 2014), hal. 125-135.

12 I. Awan, "Muslim Prisoners, Radicalizations and Rehabilitation in British Prisons", Journal of Muslim Minority Affair, Vol. 33, No. 2 (2013), hal. 371-384. 
yang ada. Smith mengemukakan sebuah studi kasus yang menunjukkan bahwa lembaga pendidikan yang berada di kawasan pedesaan justru dapat berkembang menjadi sebuah kekuatan ekonomi. Tidak hanya itu, ini dapat menjadi alat penguatan kapasitas etnisitas sekaligus penyadaran hak-hak sipil berkenaan dengan kota. ${ }^{13}$ Ini berarti identitas yang terbangun dari kesukuan dan lokasi dapat digunakan secara positif untuk meraih keuntungan politik. Hanya saja, ketika ini berada dalam konteks keagamaan tidak dapat dijadikan sebagai alat perjuangan politik, karena akan medelegitimasi keberadaan agama sebagai kekuatan moral.

Teori-teori tersebut menjadi sebuah landasan bahwa sesungguhnya pesantren dalam kapasitas sebagai lembaga pendidikan memiliki potensi ekonomi. Dampaknya pada pembukaan lapangan kerja, peningkatan ekonomi kawasan, dan juga menjadi kekuatan politik ekonomi. Hanya saja diperlukan sebuah kreativitas untuk menjadikan potensi itu wujud dalam bentuk program. Spirit agama menjadi penjaga kekuatan moral dan menjadi sebuah pilar bagi tegaknya pendidikan pesantren untuk terus hadir sebagai sebuah entitas melayani. Sekaligus memberikan bekal keterampilan, akses terhadap lapangan dan kesempatan kerja.

\section{Tinjauan Penelitian Terdahulu}

Penelitian pesantren sudah menjadi perhatian arus utama kesarjanaan di Indonesia. Tidak saja peneliti dalam negeri, tetapi menjangkau peneliti asing turut memberikan kontribusi dalam wacana tentang pesantren. Bahkan sebelum Zamaksyari Dhofier memublikasikan hasil penelitiannya ${ }^{14}$, Ziemek sudah terlebih dahulu memberikan gambaran bagaiamana kondisi pendidikan pesantren Indonesia. ${ }^{15}$ Pesantren menjadi institusi yang dekat dengan masyarakat, menjadi agen pemberdayaan, sekaligus mampu memaknai permasalahan lingkungan dari jarak yang sangat dekat. Pesantren selalu menempatkan prioritas pada masyarakat, sekaligus sebagai sebuah ikatan tradisional. Potensi ini menjadi kekuatan

${ }^{13}$ Gregory. A. Smith, "The New Political Economy of Urban Education: Neoliberalism, Race, and the Right to the City", Monthly Review - An Independent Socialist Magazine, Vol. 65, No. 4 (2014), hal. 58-63.

${ }^{14}$ Zamakhsyari Dhofier, Tradisi Pesantren Studi tentang Pandangan Hidup Kiyai (Jakarta: LP3ES, 1985).

${ }^{15}$ Manfred Ziemek, Pesantren dalam Perubahan Sosial (Jakarta: P3M, 1983). 
pesantren sejak awal. Dimana tumbuh kembangnya justru berawal dan selalu berada di masyarakat.

Penelitian yang mengkaji secara khusus pelaksanaan pendidikan kewirausahaan dalam konteks minoritas muslim sudah dijalankan dalam beberapa studi kasus. Hanya saja, penelitian tersebut menumpukan pembahasan pada satu pondok pesantren saja, sehingga tidak didapatkan gambaran secara menyeluruh bagaimana kondisi pendidikan kewirausahaan di lingkungan muslim minoritas Papua Barat. Penelitian terdahulu yang berkaitan dengan kewirausahaan hanya sebatas membahas tentang pendidikan vokasi ${ }^{16}$, pengembangan kurikulum ${ }^{17}$, dan semangat kewirausahaan $\operatorname{santri}^{18}$. Penelitian tentang kewirausahaan tersebut sebatas menguraikan kondisi pada satu kasus yang tersendiri, belum dapat menggambarkan bagaimana kondisi secara umum. Sementara penelitian pesantren secara regional masih berkisar pada pembahasan tentang pendidikan agama, dan isu multikultural.

Sebagaimana ditunjukkan dalam penelitian Mohammad Talib bahwa pesantren mempunyai potensi ekonomi yang menarik. Ini ditunjukkan dengan pengembangan usaha di lingkungan pesantren. Justru dengan berdirinya sebuah pesantren dapat menjadi daya dukung bagi kehidupan ekonomi. ${ }^{19}$ Pesantren tidak lagi dipandang sebagai sebuah lembaga pendidikan semata-mata. Ini membentuk sebuah kelompok kecil dimana perputaran barang dan jasa akan mengikuti segala aspek kegiatan yang berlangsung. Hanya saja ekonomi itu bukanlah dengan tujuan untuk membentuk kapitalisasi. Tetapi semata-mata untuk menunjang pelaksanaan program pendidikan pesantren.

Bagi muslim Indonesia, pesantren hadir tidak saja dalam fungsi sebagai lembaga pendidikan agama saja. Pesantren memainkan peran lebih dari itu, termasuk dalam beberapa hal yang justru melampaui peran pesantren sebagai

16 Ismail Suardi Wekke, "Pendidikan Islam dan Pemberdayaan Masyarakat (Tinjauan Pendidikan Vokasional Pesantren Roudhotul Khuffadz, Sorong)", Jurnal Kajian Islam Interdisipliner, Vol. 10, No. 1 (Desember 2011), hal. 23-53.

${ }^{17}$ Ismail Suardi Wekke, "Pesantren dan Pengembangan Kurikulum Kewirausahaan: Kajian Pesantren Roudhothul Khuffadz Sorong Papua Barat", Jurnal Penelitian Sosial Keagamaan Inferensi, Vol. 6, No. 2 (Desember 2012), hal. 205-226.

${ }^{18}$ Ismail Suardi Wekke, Pendidikan Agama dan Kewirausahaan Santri: Kajian Pesantren Rodhotul Khuffadz Sorong Papua Barat, Makalah dalam Temu Ilmiah Nasional Psikologi 2012 di Fakultas Psikologi, Universitas Airlangga, 20-21 November 2012, hal. 269-291.

${ }^{19}$ Mohammad Talib, "The Moral Economy of the Madrasa: Islam and Education Today", Journal of Islamic Studies, Vol. 24, No. 2 (2013), hal. 252-255. 
institusi pendidikan keagamaan. Di Surakarta, Pesantren al Muayyad Windan memediasi konflik warga. ${ }^{20}$ Pesantren juga hadir sebagai agen pemberdayaan masyarakat. $^{21}$ Ini bukan karena terbentuk secara spontanitas, tetapi sudah melembaga menjadi peran yang optimal. Walaupun berasal dari sebuah langgar kecil, tetapi perhatian terhadap masyarakat sekitarnya selalu saja ditempatkan sebagai hal yang utama. ${ }^{22}$

Ilmu agamalah yang menjadi nilai dan ajaran yang ditransmisikan pesantren. Penyebaran Islam yang kemudian disebut dakwah adalah sisi utama pesantren yang berkembang dalam bentuk multidimensi. Dalam tradisi pesantren, pembacaan kitab klasik yang diistilahkan kitab kuning menjadi sebuah aktivitas utama. Pilihan ini dilakukan semata-mata karena pertimbangan ketersediaan, kemampuan sumber daya, dan perkembangan kekinian saat itu, namun Ryoo dan Linn kemudian membuktikan bahwa dengan pola pembelajaran seperti ini, pembacaan disertai dengan penjelasan secara memadai menjadi sebuah strategi pembelajaran yang membentuk interaksi positif. $^{23}$ Dengan metode sorogan, bandongan dan wetonan yang dijalankan secara bergantian dan juga disesuaikan dengan keadaan pembelajaran, menjadikan sebuah konsep ditranformasi menjadi energi. Pola ini, santri kemudian menyerap informasi sekaligus mengartikulasilan proses yang ada dan kemudian mendorong adanya diskursus untuk memperoleh pemahaman yang utuh.

Penelitian-penelitian tersebut menjadi sebuah telaah khusus bagaimana posisi pesantren Indonesia. Peneliti yang hadirpun tidak saja dari kalangan internal. Tetapi menarik untuk dikaji termasuk dari perguruan tinggi luar negeri. Bahkan ketika tradisi intelektual Indonesia belum berkembang, para sarjana luar negeri sudah membahas pesantren-pesantren Indonesia. Walaupun demikian, penelitian ini menemukan relevansinya dengan mengkaji secara khusus pesantren

20 Anas Aijuddin, Peran Pesantren dalam Mediasi Konflik Keagamaan di Surakarta (Jakarta: Badan Litbang dan Diklat Kementerian Agama RI, 2012), hal. 231-235.

${ }^{21}$ Ismail Suardi Wekke, "Religious Education and Empowerment: Study on Pesantren in Muslim Minority West Papua”, Jurnal Ilmu-ilmu Keislaman Miqot, Vol. XXXVII, No. 2 (JuliDesember 2013), hal. 374-395.

${ }^{22}$ Imam Bawani, Tradisionalisme dalam Pendidikan Islam (Surabaya: al-Ikhlas, 1993), hal. 117.

${ }^{23}$ Kihyun Ryoo dan Marcia C. Linn, "Designing Guidance for Interpreting Dynamic Visualizations: Generating Versus Reading Explanations", Journal of Research in Science Teaching, Vol. 51, No. 2 (Februari 2014), hal. 147-174. 
di minoritas muslim. Upaya pesantren di Papua Barat untuk melakukan sinergi dengan lingkungan yang didiaminya merupakan pilihan dengan mengimplementasikan pendidikan kewirausahaan. Ini merupakan pilihan yang ditetapkan sesuai dengan keadaan dan konteks alam yang melingkupinya. Sehingga akan memungkinkan sebuah pencapaian yang dibangun dengan kekuatan yang ada.

\section{Metode Penelitian}

Penelitian ini bertujuan untuk mendeskprisikan sebuah pola yang menggunakan keterampilan wirausaha sebagai bagian dari pelaksanaan program pendidikan. Penelitian dilaksanakan di masyarakat minoritas muslim dengan pertimbangan utama ada kondisi sosial yang berbeda antara muslim mayoritas dengan muslim minoritas. Walaupun dalam konteks secara umum, muslim Indonesia menikmati posisi sebagai mayoritas. Tetapi persentuhan ide dengan masyarakat lain yang berbeda pilihan keberagamaan memunculkan sebuah interaksi dengan nuansa yang tidak sama. Seperti di Papua Barat, penelitian ini mengeksplorasi empat pesantren yang menjadi tempat penelitian dimana kesemuanya lembaga tersebut kemudian bersama-sama mengusung sebuah program untuk peningkatan kapasitas dan juga pelatihan keterampilan. Sehingga ketika seusai menyelesaikan pendidikan agama semata-mata tidak menjadikan keberadaannya yang tidak relevan dengan lingkungan sekitar. Tetapi justru tetap dapat bertahan dengan memanfaatkan keadaan sosial dan kondisi alam yang ada. Untuk mendapatkan data-data tersebut, maka analisis situasional-pragmatik dilakukan sehingga data yang dikumpulkan merupakan struktur yang terjadi dalam pelaksanaan sebenarnya. ${ }^{24}$

Pertimbangan ini menjadi sebuah dasar dalam memutuskan tempat penelitian. Adanya unsur pendidikan kewirausahaan yang menjadi ciri utama dalam menentukan lokasi penelitian. Pengumpulan data dilaksanakan selama enam bulan secara bertahap dengan dua metode yaitu pengamatan dan wawancara. Keduanya dilaksanakan secara bersamaan sekaligus sebagai upaya

${ }^{24}$ Shan L. Pan dan Barney Tan, "Demystifyng Case Research: A Structured-pragmaticsituasional (SPS) Approach to Conducting Case Study", Information and Organization, Vol. 21, No. 3, (November 2011), hal. 161-176. 
untuk melakukan triangulasi data. Analisis argumentasi dilakukan untuk menguji bagaimana pernyataan tersebut mengilustrasikan pelaksanaan dan juga terapan sebagaimana pendekatan filosofis. ${ }^{25}$ Kelengkapan data yang lainnya diperoleh melalui analisis dokumen. ${ }^{26}$ Dengan tidak menggunakan intervensi sama sekali, maka bentuk partisipasi yang dilaksanakan adalah tidak berpartisipasi. Materi yang berkenaan dengan program yang berkaitan ditelurusi tanpa mengganggu kelangsungan program yang sementara berlangsung. Sehingga kehadiran penelitian juga tidak menjadi sebuah efek gangguan.

Penelitian dilaksanakan di Kota Sorong dan Kabupaten Sorong, kedua lokasi ini adalah ditempati muslim dalam populasi yang signifikan dibandingkan dengan kabupaten lain di Papua Barat. Walaupun Kabupaten Fak-fak dan Kabupaten Kaimana, juga ditempati muslim dalam angka yang memadai tetapi lembaga pendidikan yang menggunakan pola pesantren sekaligus menjadikan pelatihan keterampilan sebagai bagian dari kegiatan pendidikan belum dilaksanakan secara terprogram. Lokasi penelitian yang menjadi target hanyalah lembaga pendidikan yang menjadikan pelatihan keterampilan berwirausaha sebagai bagian dari program pendidikan. Sementara pesantren di Fak-fak dan Kaimana, masih menyelenggarakan pendidikan diniyah secara tradisional. Terdapat juga lembaga yang sudah melaksanakan sistem pendidikan pesantren modern tetapi sebatas pada pembelajaran bahasa asing saja. Ini juga karena lingkungan perkotaan yang tidak memungkinkan pelaksanaan pendidikan sebagaimana kriteria yang ditetapkan. Penelitian ini menggunakan prinsip-prinsip pendidikan dalam penentuan kriteria untuk menyeleksi subyek penelitian. ${ }^{27}$

Empat pesantren terpilih yang dijadikan obyek studi lapangan adalah Pesantren Rodhotul Khuffadz, di Aimas. Kedua, Pesantren Minhajut Thalibin, di Aimas. Ketiga, Pesantren Hidayatullah, di Mayamuk. Terakhir, Pesantren Nurul Yaqin, Mayamuk. Semua pesantren ini memenuhi kriteria antara lain pendidikan

${ }^{25}$ Michael A. Westerman, "Examining Arguments Againts Qualitative Research: Case Study Illustrating the Challenge of Finding a Sound Philosophical Basis for a Human Sciences Approach to Psychology", New Ideas in Psychology, Vol. 32 (Januari 2014), hal. 42-58.

26 L. L. Iversen, "Presenting The Iterative Curriculum Discourse Analysis (ICDA) Approach", British Journal of Religious Education, Vol. 36, No. 1 (Januari 2014), hal. 53-71.

${ }^{27}$ E. Lahelma, S. Lappalainen, R. Meitola, dan T. Plamu, "Discussions That 'Tickle Our Brains': Constructing Interpretations Through Multiple Ethnographic Data-Sets", Ethnography and Education, Vol. 9, No. 1 (2014), hal. 51-65. 
berpola pondok pesantren, ada program pengembangan wirusaha, dan kegiatan berkelanjutan untuk pelatihan keterampilan santri. Tiga unsur ini dicek dan terpilihlah empat pesantren tersebut di atas. Pemilihan beberapa lembaga didasarkan pada proses penelitian dengan menggunakan prinsip studi kasus. Dapat saja menggunakan beberapa tempat dengan menggunakan kriteria yang sama. $^{28}$

\section{Pendidikan Islam dan Upaya Integrasi Program}

Sebagai sebuah adaptasi dari tuntutan masyarakat yang berada sebagai lingkungan yang mengitari lembaga, menjadi sebuah keharusan untuk senantiasa memperhatikan keberadaan sosial masyarakat sebagai sebuah elemen dalam pengembangan pendidikan. Sebagai bagian dari aktivitas pendidikan, maka tahapan program ini hanya menjadikan pelatihan keterampilan berwirausaha sebagai pengenalan, kegiatan tambahan, dan juga melengkapi program utama. Sehingga aktivitas yang dilakukan bersama santri dengan guru merupakan sebuah langkah terobosan untuk mendukung kegiatan-kegiatan pondok.

Secara detail, hasil penelitian ini akan dibagi menjadi empat sub bagian yaitu (1) Pendidikan Islam di Minoritas Muslim; (2) Lingkungan dan Kondisi Sosial dalam Harmoni; (3) Pendidikan Berwawasan Kewirausahaan, dan (4) Masa Depan Pendidikan Islam di Papua Barat.

\section{Pendidikan Islam di Minoritas Muslim}

Bentuk pendidikan madrasah menjadi pilihan utama bagi muslim Papua Barat. Ini karena di sekolah umum, agama Islam tidak diajarkan secara memadai, terutama karena kekurangan guru. Di pedalaman, sebuah sekolah dasar hanya memiliki guru kelas dan sama sekali tidak mendapatkan alokasi guru agama. Walaupun terdapat guru agama, namun mereka mengajarkan agama lain, sehingga dengan guru non-muslim akan menyukarkan bagi murid belajar agama Islam. Dalam beberapa sekolah, akhirnya guru agama dengan gelar sarjana agama mengajar dengan Sehingga murid-murid tidak belajar agama sebagaimana mestinya. Begitu juga dengan adanya guru muslim yang mengajarkan agama

${ }^{28}$ Carsten Schneider dan Ingo Rohlfing, "Combining QCA and Process Tracing in SetTheoretic Multi-Method Research", Sociological Methods and Research, Vol. 42, No. 4 (November 2013), hal. 559-597. 
Islam tetapi tidak memiliki kompetensi keilmuan formal sehingga menjadi kendala dalam proses belajar mengajar. Sementara guru mengaji juga tidak tersedia di lingkungan yang ditempati. Keadaan ini ditambah dengan tidak adanya pendidikan berupa Taman Pendidikan al-Quran, karena masjid yang terdekat dapat dicapai hanya dengan naik perahu. Untuk itu, orang tua memilih untuk mengirim anaknya belajar ke madrasah atau pesantren. Dengan pola asrama, maka kendala ini dapat diatasi sekaligus memberikan kesempatan bagi anak untuk belajar mandiri.

Faktor lain yang pendorong bagi orang tua mengirimkan anaknya ke madrasah adalah pergaulan. Seorang individu muslim yang belajar bersama-sama dengan pelajar lain yang berbeda agama, akan teracuni dengan pola yang sama sekali jauh dari tuntunan Islam. Dengan pergaulan itu, tidak dapat lagi mempraktekkan sesuai dengan apa yang menjadi ajaran Islam. Ketika berada di sekolah umum, maka kesempatan beribadah dan juga mempelajari agama akan terbatas. Sehingga dengan berada di lingkungan madrasah kesempatan untuk mengekspresikan diri sesuai dengan identitas keislaman dapat dilakukan. Walaupun juga di sekolah itu tidak ada larangan dan hambatan tetapi fasilitas seperti mushollah tidak tersedia. Di samping itu, kantin atau tempat makan bercampur dengan makanan yang juga disantap oleh orang lain yang terdiri atas bahan-bahan yang tidak dibolehkan oleh agama. Perjumpaan dengan agama lain inilah dalam keseharian yang menjadi masalah jika berada dalam konteks pendidikan karena berada dalam jangka waktu yang panjang.

Madrasah dikembangkan oleh masjid tetapi ini hanya dilakukan di masjidmasjid besar. Itupun banyak tempat terpusat di Kota Sorong dan ibukota Kabupaten Sorong, Aimas. Pengembangan taman pendidikan al-Quran di masjid juga hanya berada di wilayah yang ditempati muslim. Sementara umat Islam yang menempati wilayah seperti Tanjung Sauka dan Makbon mengalami kesulitan dalam mendapatkan pelajaran agama. Sekalipun itu masjid, mereka kemudian tidak dapat menjalankan shalat lima waktu di masjid karena jarak tempuh jauh antara rumah penduduk dengan tempat ibadah.

Sudah mulai pula berkembang Sekolah Islam Terpadu, sekolah ini hanya berada di ibukota distrik, seperti Sekolah Dasar Islam Terpadu (SDIT) al-Ghoraba 
di SP 2. Ini sudah berjalan satu tahun ajaran. Sementara SDIT di Kota Sorong sudah melahirkan alumni yang saat ini berada di Sekolah Menengah Islam Terpadu (SMPIT). Bentuk SMPIT ini jugalah yang digunakan Pesantren Nurul Yaqin sebagai pilihan kelembagaan untuk sekolah formal bagi santri untuk tingkatan awal.

Sementara itu untuk pondok pesantren yang menyelenggarakan sekolah formal, kelengkapan pendidikan agama disediakan melalui dua pola yaitu madrasah diniyah dan kurikulum pondok. Pada jam pelajaran formal ada muatan lokal yang dijadikan sebagai bagian pelajaran. Sementara usai jam sekolah, di pondok juga diterapkan sebuah kurikulum untuk menjadi aktivitas pembelajaran bagi santri. Jika di SMPIT pelajaran agama terintegrasi dengan mata pelajaran lainnya. Sementara di Madrasah Aliyah jam yang digunakan setelah pendidikan formal berlangsung. Penetapan program ini dilaksanakan oleh pondok dengan penetapan dari yayasan. Walaupun pondok secara tradisi sudah melaksanakan pendidikan agama, tetapi pemilihan istilah madrasah diniyah sebagai langkah administratif untuk keterhubungan dengan program Kementerian Agama.

Gambaran ini menunjukkan ada kesulitan tertentu dalam mendapatkan pendidikan agama bagi keluarga muslim terutama di pelosok dan pulau-pulau. Ketiadaan guru menjadi persoalan utama. Jikalaupun ada guru, tidak sesuai dengan keahlian. Begitu juga dengan kondisi wilayah yang tidak didiami warga muslim dalam jumlah memadai untuk mendirikan masjid. Di beberapa tempat tersedia mushollah tetapi tenaga pengajar yang dapat menjalankan proses belajar mengajar tidak didapatkan. Sehingga kebutuhan pendidikan anak diatasi dengan mengirim ke madrasah yang menggunakan pola asrama untuk memudahkan proses pendidikan. Ini juga bermakna mereka akan mendapatkan pelajaran secara reguler karena adanya tuntunan guru, program yang sudah teratur, serta pembinaan identitas muslim yang lebih sesuai dengan kepribadian muslim.

\section{Lingkungan dan Kondisi Sosial dalam Harmoni}

Perjumpaan komunitas muslim dengan penganut agama lain terbentuk sejak perkembangan masyarakat di Papua. Bahkan sebelum itu bernama Papua dalam kerangka Republik Indonesia. Toleransi, harmoni, dan kesediaan hidup 
bersama sudah merupakan bagian dari praktik yang berlangsung di masyarakat. Ini juga karena faktor pilihan beragama dalam keluarga yang heterogen. Dalam tradisi budaya lokal Fak-fak dikenal istilah "satu tungku tiga batu". Ini bermakna dalam satu rumpun keluarga kerap dalam satu keluarga ada tiga agama yang berbeda yaitu Islam, Protestan dan Katolik. Ini bermakna, agama-agama yang berbeda merupakan pilihan masing-masing individu tetapi tetap saja menopang keberadaan keluarga sebagai sebuah kesatuan. Keberagamaan dan pilihan akan keyakinan menjadi suatu hal yang teramat lumrah dalam lingkaran keluarga. Untuk itu, setiap individu kemudian berusaha untuk mempertahankan keyakinan tanpa perlu terganggu dengan kehadiran pihak lain yang berbeda agama.

Perayaan hari besar agama menjadi momentum menjalin persaudaraan. Anggota keluarga yang merayakan hari besar dikunjungi, turut bersilaturahmi, dan juga saling mengucapkan selamat. Sementara ketika perayaan Natal, umat Kristiani menyediakan makanan dan minuman yang justru disiapkan oleh tukang masak muslim. Tetangga dan kerabat muslimpun turut hadir dan memberikan uapan selamata atas perayaan itu. Anggota keluarga saling membantu saat ada anggota keluarga yang lain merayakan hari raya. Jalinan ini semata-mata karena alasan persaudaraan. Maka, rumah orang tua biasanya memiliki ruang tengah yang lebih besar dibanding anak-anaknya. Ini untuk memberi kesempatan siapapun yang merayakan hajatan atau perayaan keagamaan, mereka berkumpul di rumah orang tua.

Begitu juga dalam acara Musabaqah Tilawatil Quran (MTQ) dan Seleksi Tilawatil Quran (STQ) yang dilaksanakan secara bergantian. Saat diperlukan paduan suara, maka kelompok paduan suara dari gereja akan membantu selama kegiatan berlangsung. Pemuda gereja turut dalam kepanitiaan untuk menyukseskan acara. Selanjutnya sejak persiapan sampai pembubaran panitia, pendeta dan perwakilan gereja bersama-sama dengan Lembaga Pengembangan Tilawatil Quran (LPTQ) berusaha mempersiapkan acara, termasu dalam urusan penggalangan dana. Tenaga, pikiran, dan pendanaan mereka sumbangkan untuk menghelat acara MTQ dan STQ. Baik itu di tingkat kabupaten dan kota, demikian pula di tingkat provinsi. Walaupun Wakil Bupati atau Wakil Walikota berasal dari 
non-muslim, secara sukarela mereka menjadi Ketua LPTQ, lembaga yang khusus mengurusi pengembangan baca tulis al-Quran.

Saat tarawih dan shalat hari raya, pemuda gereja dengan sukarela dan dikoordinir oleh pemuda gereja berjaga-jaga mengatur lalu lintas. Sebaliknya, saat Natal, Paskah, dan Pekabaran Injil, remaja masjid yang dikoordinir Badan Komunikasi Pemuda Remaja Masjid (BKPRMI) menjaga keamanan, mengatur parkir, dan menertibkan lalu lintas. Gotong royong seperti ini berlangsung sejak dulu. Bahkan untuk soal makan dan minum para penjaga itu mereka juga urunan dalam menyediakannya.

Kerjasama dan saling pengertian antar umat beragama menjadi kunci kehidupan masyarakat. Termasuk dalam internal umat beragama sendiri. Ketika bekerja sama dengan warga yang menganut agama berbeda merupakan praktik yang jamak dilakukan, maka ukhuwah antar umat Islam sendiri sudah terjalin. Dalam kondisi ini dapat dicermati melalui pembangunan sarana ibadah dan juga pengembangan lembaga pendidikan. Salah satu prakarsa komunitas muslim adalah bagaimana menyiapkan sarana pendidikan untuk menjadi alternatif bagi keluarga dalam menyediakan pendidikan dengan penguatan pada pelajaran pendidikan Islam. Lembaga pendidikan seperti pesantren dan madrasah menjadi pilihan utama. Ini dikembangkan melalui yayasan ataupun penambahan aktivitas dari sebuah masjid.

Masjid al-Akbar di kota Sorong merupakan salah satu masjid terbesar, sejak 2010 sudah membuka Madrasah Tsanawiyah. Ini dilakukan karena keterbatasan penerimaan siswa di Madrasah Tsanawiyah Model. Sementara peminat yang mendaftar melebihi kapasitas. Sehingga dengan adanya madrasah di lingkungan masjid ini, akan mampu menjawab kebutuhan umat Islam. Lahan yang dimiliki masjid kemudian dilengkapi dengan bangunan sekolah, termasuk dengan penyediaan tenaga pengajar yang memiliki kompetensi. Semuanya didukung dari dana jamaah masjid. Prakarsa pengembangan aktivitas ini juga awalnya dari kekhawatiran jamaah masjid akan daya tampung madrasah yang sudah ada, tidak mampu lagi memenuhi kebutuhan umat Islam.

Masih di kota Sorong, masjid Al-Jihad mengelola sekolah dasar. Awalnya hanya sebuah masjid. Dengan usaha bersama jamaah, sekolah dasar al-Jihad 
berdiri dan menjadi salah satu sekolah unggulan. Masjid dan sekolah menjadi kesatuan. Pendidikan dilaksanakan dengan menjadikan masjid sebagai bagian integral dari proses pendidikan. Shalat berjamaah dhuhur merupakan bagian dari program pendidikan, sekaligus setiap hari juga shalat Dhuha berjamaah. Muridmurid dibiasakan untuk mengikuti shalat jamaah. Pengembangan ini dijalankan karena sekolah dasar yang ada belum mendapatkan alokasi guru agama. Sehingga murid-murid tidak belajar pendidikan agama Islam. Begitu pula dengan pergaulan lingkungan sekolah dan pemukiman, menjadikan anak-anak muslim tidak mampu lagi mengenali mana yag boleh dilakukan dan tidak boleh sesuai dengan ajaran agama. Dengan adanya sekolah ini, maka identitas muslim dapat dibangun dan diajarkan di lembaga pendidikan.

Masjid menjadi kekuatan utama umat Islam di wilayah minoritas. Tidak hanya sekadar menjadi sebuah tempat ibadah. Tetapi juga dijadikan sebagai pusat kegiatan bersama. Masjid juga dilengkapi dengan fasilitas mobil kesehatan. Seperti masjid di Aimas, masjid al-Ikhtiar menyediakan fasilitas pengantaran jenasah dan juga pengobatan kepada warga. Di Malanu, masjid al-Taubah menyediakan halaman masjid sebagai fasilitas untuk acara-acara kekeluargaan seperti pernikahan, khitanan, aqiqah, dll. Kelengkapan ini merupakan prakarsa jamaah dimana tidak tersedianya halaman rumah yang memadai untuk menyelenggarakan acara. Dengan adanya masjid ini, maka mengurangi kesulitan jamaah untuk melaksanakan hajatan.

Lingkungan dan kondisi sosial seperti ini, baik antar warga maupun sesama internal muslim menjadikan tumbuhnya semangat gotong royong, kebersamaan, tenggang rasa, harmoni, kepedulian, kerjasama, tolong menolong, dan saling mendukung. Dengan demikian ini juga menjadi dasar dalam kehidupan untuk saling memperhatikan. Kelangsungan bersama senantiasa diperhatikan. Begitu pula hadirnya kepedulian akan kehadiran warga lain. Praktik yang berlangsung merupakan tradisi yang sudah terbangun dan tercipta dalam kondisi masing-masing. Inilah yang kemudian menjadi tipikal dan setting lingkungan dimana mendorong perlunya sebuah pendidikan yang dapat menjadi fasilitator untuk kemajuan masyarakat. 


\section{Pendidikan Berwawasan Kewirausahaan}

Pilihan untuk mengembangkan pendidikan keterampilan adalah usaha para pengelola pesantren untuk membekali santri ketika telah menyelesaikan pendidikan agama. Tuntutan lingkungan, tidak saja memerlukan seorang muslim untuk ahli dalam agama yang dianutnya, tetapi juga diperlukan adanya keterampilan untuk hidup di tengah-tengah masyarakat. Memperhatikan ketersediaan lahan dan juga kondisi kehidupan masyarakat Papua yang dianugerahi dengan pantai dan gunung, maka pilihan utama yang dijadikan sebagai latihan tambahan adalah perkebunan, pertanian, dan perikanan. Sebuah pepatah yang digunakan oleh pengasuh pondok adalah "afdhal al-ilmi wa huwa ilm alhal" (sebaik-baik ilmu adalah ilmu yang sesuai dengan keadaan). Maka, pendidikan formal yang diajarkan di sekolah dipandang sudah memadai, sementara untuk pemahaman keagamaan dilaksanakan kurikulum madrasah diniyah. Untuk itu, waktu yang ada dimanfaatkan bagi memberikan pelatihan keterampilan santri agar dapat berlatih sejak awal bagaimana menghadapi kondisi alam Papua.

Keseluruhan santri berasal dari Papua, ini menjadikan pertimbangan keterampilan yang dilatihkan lebih mudah karena asal santri yang homogen. Tinggal memberikan kesempatan bagi santri untuk memilih bidang yang menjadi minatnya. Masing-masing santri memilih sesuai dengan orientasi kerja yang diharapkan. Tetapi untuk pelatihan diikuti secara keseluruhan santri. Tanpa membeda-bedakan minat. Pembagian dilakukan dalam kelompok kecil hanya untuk pendistribusian pekerjaan yang perlu dilaksanakan secara bersamaan. Adapun tahapan-tahapan tertentu dilaksanakan secara bersama-sama. Ini untuk memberikan kesempatan kepada santri untuk mengetahui proses secara keseluruhan. sehingga mampu memahami prosedur kerja dan juga terampil untuk melaksanakannya kembali dalam kondisi yang sesuai dengan keadaan alam yang didiaminya.

Untuk kegiatan pertanian, ini dipandu oleh seorang koordinator. Sekaligus menjadi penghubung dengan penyuluh lapangan untuk memberikan penyuluhan secara berkala kepada santri yang memilih kegiatan ini. Jenis tanaman yang dipilih untuk dirawat adalah tanaman jangka pendek seperti tomat dan cabe. 
Untuk tanaman jangka menengah seperti pisang dan pepaya. Pematangan lahan dilakukan oleh petani. Ini karena perlunya keterampilan yang memadai sekaligus santri pada pagi sampai siang berada di sekolah untuk mengikuti pendidikan formal. Sehingga kesempatan tenaga untuk mengerjakan itu tidak dapat dipenuhi.

Peternakan bebek dan ayam kampung dimulai dari program pelatihan yang dilaksanakan Kementerian Pertanian, di Jakarta. Begitu juga dengan bantuan pengadaan bibit dan perbaikan kandang. Selanjutnya disediakan pula tenaga penyuluh yang mendampingi pengajar dan santri dalam pelaksanaan kegiatan. Sebelum pemeliharaan, santri dibentuk dalam kelompok kecil yang bertugas secara kelompok. Mereka bertugas mengontrol pemberian makanan, memeriksa keadaan ternak, selanjutnya juga memanen telur. Adapun pemasaran sepenuhnya diserahkan kepada guru-guru untuk mendistribusikan kepada toko-toko yang sudah ada kerjasama sebelumnya.

Untuk hewan ternak lainnya dipelihara rusa dan sapi. Ini awalnya bermula dari usulan santri setelah melihat bebek dan ayam kampung menuai sukses. Pertimbangan utama sehingga pengadaan ternak ini terlmabat dilaksanakan karena kekahawatiran akan jalannya program yang tidak maksimal. Dimana sudah ada beberapa program yang berjalan dan juga pelaksanaan Madrasah Diniyah di sore hari setelah shalat Ashar. Namun santri-santri menunjukkan keseriusan untuk membentuk kelompok yang khusus menangani ini sehingga pimpinan pondok kemudian mengabulkan permohonan para santri. Untuk tahap awal, sebanyak lima ekor rusa dan empat ekor sapi yang diternakkan. Dalam perkembangan selanjutnya dibuatkan kandang dan juga adanya donatur yang memberikan kepercayaan bibit sapi yang dititipkan kepada pondok dengan perjanjian ketika sapi ini menghasilkan anak, maka secara bergantian pemilik dan santri akan mendapatkannya. Dengan keluasan wilayah pondok dan juga ketersediaan rumput yang menjadi kebutuhan utama ternak tidak menjadi halangan. Sehingga program peternakan ini berkembang dengan baik. Warga sekitar pondokpun kemudian turut membantu ketika ada kendala, seperti ketika kekurangan tambahan pakan ternak, maka petani membantu pondok dengan membagi persediaan yang mereka miliki. 
Di pesantren yang membina putra dan putri secara bersamaan, diberikan beberapa pembagian tugas. Santriwati bertugas untuk mengelola dapur, kantin, binatu, dan toko. Keempat unit ini melibatkan pelatihan untuk keterampilan, dan juga berhubungan dengan pengelolaan keuangan. Sementara santri mengelola pertanian dan perkebunan. Dalam beberapa pekerjaan di pertanian dan perkebunan itu dikerjakan bersama santri dan santriwati sesuai dengan porsi kerja masing-masing. Ketika lahan disiapkan, bibit juga disimpan dalam polybag, serta penyemaian, semuanya dikerjakan santri. Adapun saat perawatan, pengawasan, dan panen, itu dikerjakan oleh santriwati.

Sementara untuk perikanan, aktivitas yang dijalankan adalah pemeliharaan ikan. Di Pesantren Nurul Yaqin terdapat empat kolam yang digunakan. Dengan bekerja sama melalui perusahaan yang sudah memiliki tenaga ahli, santri dibimbing untuk memelihara ikal seperti nila, dan lele. Perusahaan ini juga menyediakan bibit secara gratis dengan perjanjian hasilnya harus dijual kembali kepada perusahaan penyedia bibit. Kelompok santri mengawasi kolam yang ditugaskan kepada mereka. Mulai dari penyiapan kolam dengan dibersihkan sampai siap diisi kembali dengan air lalu benih disebar. Ketika bibit ikan sudah dilepas ke dalam kolam, santri memantau perkembangan sekaligus memberi pakan. Saat panen, mereka menyiapkan peralatan dan memanen ikan yang ada. Tidak semuanya juga dijual, sebagian lagi diantar ke dapur untuk dinikmati sebagai sajian makan untuk semua santri.

Sementara di Pesantren Roudhotul Khuffadz, perikanan ditempatkan di kolam bekas air wudhu. Sehingga air yang sudah digunakan bersuci untuk persiapan shalat tidak terbuang. Justru tertampung untuk digunakan sebagai pengisi kolam. Ada dua aktivitas yang dilakukan berkenaan dengan perikanan ini yaitu ikan untuk pangan dan ikan hias. Ikan yang dipelihara di kolam hanya satu jenis yaitu ikan nila. Ikan ini khusus disiapkan untuk santapan oleh seluruh warga pondok. Pemeliharaan secara bersama-sama, tugas piket bagi santri menggunakan penjadwalan harian dengan tugas untuk mengawasi kolam, memberi makan, dan juga membersihkan kolam. Sementara untuk panen, santri senior ditugaskan untuk menebar jaring dan mengumpulkan ikan. Hasil panen itulah yang kemudian dimasak di dapur selanjutnya dinikmati bersama oleh seluruh warga pondok. 
Adapun untuk ikan hias, ini menjadi unit usaha pesantren. Sekaligus dilengkapi dengan pembuatan aquarium. Bagi pembeli ikan, mereka dapat memesan aquarium dengan ukuran yang diinginkan. Santri sudah mendapatkan pelatihan pengelolaan ikan hias, termasuk bagaimana membuat aquarium dengan fasilitator dari Dinas Perikanan dan Kelautan Kabupaten Sorong. Dalam paket bantuan dinas pula sudah termasuk modal usaha untuk menjalankan kegiatan ini. Santri sudah mampu menetaskan ikan, selanjutnya menempatkan ke dalam aquarium yang berbeda. Awalnya hanya ada empat aquarium untuk menampung ikan-ikan yang ada. Selanjutnya berkembang menjadi sepuluh aquarium. Di samping menjadi penampungan ikan, sekaligus juga menjadi hiasan dan kesempatan santri mendapatkan hiburan. Aquarium ditempatkan di tengah-tengah lingkungan pondok dan dekat dengan masjid. Sehingga kesempatan bagi santri untuk duduk menikmati panorama aquarium selalu dapat dilakukan bahkan dari masjidpun mereka bisa melihatnya.

Untuk keperluan sehari-hari setiap pondok menyediakan toko. Pengelolaan toko ini menjadi unit usaha pondok sekaligus menjadi tempat berlatih santri dalam mengenal usaha jual beli. Mereka ditugaskan untuk menata barang-barang, kemudian menginventariskan persediaan barang, mencatat arus kas, kebutuhan barang yang akan dibeli, mendaftar kebutuhan yang belum tersedia, dan juga mempromosikan barang baru. Kebutuhan santri disediakan, termasuk juga bukubuku untuk pelajaran sekolah dan diniyah. Sekaligus memberi kemudahan bagi pengelola pondok untuk seragam dan keperluan santri baru. Di toko juga dilengkapi dengan fasilitas photo copy. Ini diadakan untuk mendukung keperluan administrasi sekolah dimana kebutuhan untuk penggandaan dokumen merupakan kebutuhan sehari-hari. Juga penggandaan materi belajar untuk menjadi pegangan santri.

Di samping itu tersedia kantin untuk menyediakan makanan dan minuman ringan bagi santri. Dalam masa-masa istirahat atau waktu senggang ada santri yang memerlukan makanan dan minuman tambahan. Dengan adanya kantin ini akan membantu menyediakan kebutuhan itu. Orang tua yang datang menjenguk putra dan putrinya juga akan menemukan kemudahan untuk bertemu. Di kantin ini, mereka bertemu. Sekaligus menegakkan aturan bahwa tamu tidak 
diperkenankan untuk masuk sampai ke ruang tidur. Sehingga kesepaduan antara fasilitas dan aturan akan wujud sebuah langkah untuk membentuk lingkungan dan daya pendukungnya.

Toko dan kantin ini diselenggarakan oleh santri senior dengan pengawasan para guru. Sejak awal mereka dibimbing untuk membuat pembukuan yang teratur dan rapi sehingga dapat dipertanggungjawabkan. Hasilnya kembali ke pesantren sebagai dukungan dana untuk pelbagai keperluan fasilitas pesantren. Untuk dukungan bagi kelangsungan pendidikan formal ada komite sekolah dan madrasah yang turut dalam memikirkan bagaimana pendanaan. Sementara untuk pondok semata-mata diselenggarakan oleh manajemen pondok, dipandu oleh pengurus yayasan. Dewan Pembina yayasan juga selalu berusaha secara aktif untuk memberikan solusi pendanaan, termasuk hal yang terkecil seperti penyedian buku pegangan guru untuk proses belajar mengajar Madrasah Diniyah. Sehingga ada kesatuan gerak dan usaha untuk mewujudkan pengelolaan pondok dengan memberikan dukungan pendanaan secara bersama-sama.

Semua usaha ini dilaksanakan untuk membentuk sikap warga pondok untuk tidak senantiasa mengharapkan dukungan orang lain berupa sumbangan dan pemberian. Maka, sebuah kesepakatan untuk tidak meminta-minta dan tergantung pada hasil sumbangan. Sehingga tidak pernah dikeluarkan surat untuk permohonan bantuan dana. Sebaliknya jika ada donatur yang datang dan memberikan sumbangan, akan selalu diterima dengan tangan terbuka. Warga Sorong secara individu dan berkelompok terbiasa memberikan donasi kepada pesantren. Tidak saja dalam bentuk uang tunai tetapi juga dalam bentuk bahanbahan keperluan makan seperti ikan, sayur mayur, cabe, dan kentang. Begitu juga dengan dukungan fasilitas untuk keperluan kegiatan di pondok.

Usaha-usaha yang dijalankan pondok dalam hal membentuk kesadaran dan pelatihan kewirausahaan bukanlah sebagai tujuan utama. Melainkan semata-mata hanyalah sebagai kelengkapan proses pendidikan agama. Keterampilan berwirausaha sebagai usaha untuk mendukung agar ketika santri kembali ke lingkungannya dapat memperoleh bekal keterampilan untuk hidup di masyarakat. Dengan adanya keterampilan ini, maka peran serta mereka di masyarakat dapat lebih bermakna. Terlebih lagi, walaupun sudah memiliki kemampuan pemahaman 
keagamaan ini akan paripurna kalau para santri itu mampu menghidupi dirinya sendiri tanpa perlu tergantung kepada orang lain. Dalam posisi inilah, pesantren memasukkan wirausaha sebagai bagian program pendidikan. Sehingga akan menhasilkan lulusan yang dapat berkiprah bagi diri dan masyarakat sekitarnya.

\section{Masa Depan Pendidikan Islam di Papua Barat}

Awalnya pengembangan pendidikan Islam di Kota Sorong dan Kabupaten Sorong dimulai dari pendirian panti asuhan, seperti di Pesantren Roudhotul Khuffadz, Aimas dan Pesantren Nurul Yaqin, Mayamuk. Bahkan di Pesantren Nurul Yaqin sejak 2013 diputuskan untuk menggabungkan manajemen pesantren dan panti asuhan. Ini dilakukan dalam rangka memadukan kebijakan dan operasionalisasi keduanya sehingga berjalan secara bersamaan. Pendirian panti asuhan sebagai upaya untuk memberikan fasilitas pendidikan bagi generasi muda yang masih dalam usia sekolah dan mereka bertempat tinggal di pulau. Akses transportasi yang tidak memungkinkan untuk kembali ke rumah keluarga setiap saat selama menempuh pendidikan, menjadikan salah satu latar belakang mengapa harus mendirikan panti asuhan dalam memberikan tempat tinggal bagi mereka selama mengikuti pendidikan di pesantren. Mereka diberikan fasilitas tempat tinggal, pembebasan pembiayaan, dan juga fasilitas lainnya untuk menopang semangat belajar. Sampai 2010, semua santri yang ada tidak membayar apapun untuk menuntut ilmu. Seiring bertambahnya santri dan juga dengan kemampuan orang tua untuk membiayai pendidikan anak-anaknya yang dimasukkan ke pesantren, maka mereka kemudian secara rutin membayar iuran.

Begitu pula di Pesantren Hidayatullah, ini tidak hanya satu lokasi di Papua Barat, tetapi setiap kabupaten dalam Provinsi Papua Barat terdapat satu Pesantren Hidayatullah. Santri yang bermukim di pesantren, walaupun Hidayatullah tidak menggunakan bentuk kelembagaan panti asuhan, namun tidak membebani santri dengan pembiayaan satu senpun. Pesantren menerima santri dan memberikan kesempatan belajar, termasuk jika santri memilih untuk menempuh pendidikan formal di sekolah sekitar pesantren. Maka, pesantren mendampingi, membina dan juga memberikan pelatihan untuk melengkapi kemampuan yang telah diperoleh dari pendidikan formal. 
Organisasi santri menjadi sebuah pendukung bagi berjalannya program yang ditetapkan. Santri senior yang berada di Madrasah Aliyah menjadi mentor bagi santri yang berada di tsanawiyah. Pengalaman dan keterampilan yang sudah didapatkan santri senior kemudian ditransfer ke santri yunior sekaligus juga menjadi sebuah kesempatan dalam memantapkan pengalaman mereka dengan metode pendidikan sebaya. Ini berfungsi ganda, kekurangan tenaga pengajar dan juga sebagai proses kaderisasi. Mereka belajar tentang tanggung jawab, metode mengajar, dan menggunakan kemampuan untuk dikolaborasi. Kelompok kecil dengan bimbingan santri senior ini menjadi sebuah kekuatan dengan jumlah yang memadai. Dengan komposisi kelompok ditambah dengan tenaga pengajar, dan juga penyuluh menjadi tim kerja yang dapat diandalkan.

Kekuatan pendidikan Islam di Papua tidaklah mengandalkan kharisma dan juga personalitas tertentu. Tidak adanya kiyai atau pemimpin agama dengan keilmuan yang handal bukanlah penghalang bagi tumbuhnya lembaga pendidikan. Justru dengan tidak adanya figur seperti ini kekuatan kelompok menjadi dominan. Pembagian kerja, pendelegasian wewenang, dan saling mendukung merupakan pilar bagi berjalannya fungsi-fungsi manajemen. Kebersamaan yang membentuk identitas komunitas kemudian menjadi sebuah institusi yang dapat bergerak dan menumbuhkembangkan lembaga. Perubahan individu dalam masyarakat dapat diusahakan. Ini menjadi tumbuhnya kelompok kecil yang berdaya dan dapat saja menjadi dasar bagi transformasi selanjutnya.

Keberadaan lembaga pendidikan dengan segala kekurangan yang mengiringi dapat menjadi sebuah wahana bagi perkembangan sosial di Papua Barat. Kekuatan tim dan berkembangnya kelompok-kelompok yang menjadikan pendidikan sebagai kekuatan sosial merupakan bagian dari upaya integrasi sosial. Praktik keberagamaan dilandasi dengan paham yang diperoleh dari lembaga pendidikan. Tidak saja tentang nilai agama, identitas, dan kemampuan tetapi mencakup pada keterampilan hidup dan bagaimana menempatkan diri di tengah masyarakat. Semuanya ini difasilitasi oleh pendidikan pesantren sebagai lembaga yang menyerap aspirasi dari lingkungan. Dengan memahami kebutuhan masyarakat, maka pesantren sejak awal menjadi bagian dari gerakan masyarakat 
itu sendiri. Inilah yang menjadi landasan bagi gerak maju pesantren masa kini untuk masa yang akan datang.

\section{E. Implikasi Teoritis}

Penelitian ini menunjukkan pesantren di minoritas muslim menjadikan program kewirausahaan sebagai bagian dari pola pendidikan pondok. Dengan adanya program ini dimaksudkan sebagai latihan ekstra kurikuler bagi santri selama menempuh pendidikan agama. Model ini juga dapat dijadikan sebagai pembentukan karakter peserta didik. Dimana keterlibatan dengan sebuah aktivitas yang memberdayakan dapat mengarahkan santri ketika sampai usia dewasa untuk selalu menghindari keterlibatan dalam aksi kejahatan. Wainright dan Nee menunjukkan sebuah penelitian di anak-anak usia 10 sampai 18 tahun. Mereka menyimpulkan bahwa ada potensi yang dapat dicegah dengan memberikan pengalaman berupa aktivitas pendidikan dan mentoring. ${ }^{29}$ Maka, dengan memperkenalkan sebuah kegiatan yang menggunakan strategi kewirausahaan dapat menjadi sebuah usaha dalam memberikan kemampuan memorik bagi santri yang pada saatnya dapat ditransformasikan sebagai kekuatan untuk kehidupan selanjutnya.

Penelitian ini juga menunjukkan adanya sinergitas antara pengelola pondok dengan masyarakat sekitar yang mendiami kawasan pesantren. Kerjasama, dukungan, dan saling membantu merupakan pilar bagi terselenggaranya program ini. Pelibatan peran serta masyarakat, penyuluh, dan juga birokrasi untuk mendukung program-program pondok merupakan sebuah usaha agar adanya komunikasi ini dapat membantu meningkatkan kualitas pelaksanaan kegiatan. Tidak semata-mata hanya dijadikan sebagai sebuah latihan tanpa menghasilkan profit, tetapi lebih dari itu diharapkan adanya hasil usaha dari kegiatan ini dapat kembali untuk kesejahteraaan warga pondok. Sekaligus mengurangi beban orang tua santri dalam pembayaran dan iuran untuk kelangsungan pondok. Ini berarti bahwa aktivitas ini juga memiliki dimensi sosial

${ }^{29}$ Lucy Wainwright dan Claire Nee, "The Good Lives Model - New Directions for Preventative Practice With Children?", Psychologhy Crime \& Law, Vol. 20, No. 2 (Februari 2014), hal. 166-182. 
yang berdampak pada penguatan hubungan orang tua santri dengan pondok. ${ }^{30}$ Terdapat dampak ganda yang menjadi hasil dari proses pendidikan yang dilaksanakan. Pada saat yang sama didapatkan hasil untuk internal pondok, juga berkontribusi bagi secara siginifikan bagi agenda organisasi.

Hasil penelitian juga menunjukkan pesantren didukung oleh manajemen yang kuat dengan program yang diiplementasikan sesuai dengan kebutuhan setelah melalui sebuah pendalaman. Dengan demikian, apa yang terlaksana bukanlah program yang jauh dari realitas keseharian. Kemampuan melaksanakan diukur dari ketersediaan sumber daya, minat dan juga dukungan tenaga ahli. Dengan demikian akan terbentuk sebuah kekuatan internal dalam santri untuk senantiasa mengandalkan dirinya sendiri. Terbentuknya pendidikan seperti sesungguhnya merupakan misi pendidikan internasional. Marginson menjelaskan bahwa kecenderungan pendidikan dunia saat ini dengan adanya pembentukan identitas yang kuat untuk menghadapi pilihan kosmopolitan yang menjadi ciri bagi setiap komunitas. ${ }^{31}$ Dengan kemampuan seperti ini, maka santri dapat menempatkan dirinya dalam lingkungan kerja dan juga interaksi dengan masyarakat lain.

Ini menjadi sebuah sumber bagi tumbuhnya pengetahuan yang diawali dari pembacaan akan keterlibatan masyarakat. Ide kosmopolitan masyarakat menjadi sebuah agenda bagi kurikulum. Seperti di Korea, justru tantangan masyarakat multikultural menjadikan perlu ada sebuah interpretasi materi belajar dalam pembentukan kurikulum. Sehingga identitas dan keterampilan peserta didik akan mengalami perkembangan sesuai dengan tantangan yang ada. ${ }^{32}$ Ini bermakna pendidikan pesantren telah melampau kekawatiran sebagaimana yang diterapkan di Korea. Walaupun tidak melalui sebuah penelitian yang mendalam dan waktu yang panjang, pilihan pendidikan pesantren senantiasa tetap relevan dengan perkembangan terkini.

30 Paul Copeland dan Scott James, "Policy Windows, Ambiguity, and Commission Entreprneurship: Explaining the Relaunch of the European Union's Economic Rfeorm Agenda", Journal of European Public Policy, Vol. 21, No. 1 (Januari 2014), hal. 1-19.

31 Simon Marginson, "Student Self-Formation in International Education", Journal of Studies in International Education, Vol. 18, No. 1 (Februari 2014), hal. 6-22.

${ }^{32}$ Kyunghee So, Sangeun Lee, Jiae Park, dan Jiyoung Kang, "The Idea of Cosmopolitan in Korea's National Curriculum", Asia Pacific Journal of Education, Vol. 34, No. 1 (Januari 2014), hal. 1-14. 
Sebuah lembaga pendidikan keagamaan sejak awal hanya dikembangkan untuk membekali kemampuan beragama. Namun sebagai bagian dari minoritas muslim, ini tidak cukup memadai. Maka, salah satu pilihan yang diambil adalah melengkapi proses pendidikan dengan mengacu kepada suasana lingkungan yang menjadi wahana tumbung kembang peserta didik. Olehnya, keberadaan program pertanian, peternakan, dan perikanan semata-mata karena berasal dari identifikasi lapangan. Dengan pendekatan seperti ini, maka sesungguhnya pesnatren sudah menumbuhkembangkan sebuah jalan dalam merepresentasikan keberadaan pengetahuan yang sudah ada di masyarakat. Hong dan Scardamalia menjelaskan bahwa pengetahuan sesungguhnya sudah berada di masyarakat. Hanya saja perlu sebuah usaha untuk membangun itu sekaligus kemudian mendiskusikan bagian kunci yang menjadi pendukungnya. Selanjutnya, direfleksikan menjadi sebuah program yang terlaksana dengan mengandalkan masyarakat sebagai pendukung utamanya. $^{33}$

Akhirnya, praktik pendidikan yang berlangsung di kawasan minoritas muslim senantiasa mengalami dinamika dengan lingkungan yang menjadi wahana perkembangan. Walaupun terdapat debat yang berkepanjangan tetapi pergaulan antara warga baik muslim maupun dengan non-muslim menjadi sebuah kesempatan untuk melakukan kerjasama. Ini menjadi sebuah tambahan data bagi penelitian Shavit yang mengkaji pertanyaan tentang pertemanan antara muslim dan non-muslim ${ }^{34}$. Dengan adanya sinergitas seperti ini akan akan memberikan pengalaman spiritual tersendiri. Dimana perjumpaan dengan warga yang berbeda akan menjadi kesempatan dalam membangun kepribadian terbuka dan menerima perbedaan yang paling dasar yaitu soal keyakinan. Saleem, Treasaden, dan Puri menunjukkan sebuah fakta bahwa bagi masyarakat Inggris, dengan pergaulan masyarakat yang berbeda keyakinan justru akan menguatkan pandangan masingmasing pemeluk agama dengan tetap memegang teguh keyakinan yang

${ }^{33}$ Huang-Yo Hong dan Marlene Scardamalia, "Community Knowledge Assesment in a Knowledge Building Environment”, Computers \& Education, Vol. 71 (Februari 2014), hal. 279288.

${ }^{34}$ U. Shavit, "Can Muslims befriend Non-Muslims? Debating al-Wala wa al-Bara (Loyalti and Disavowal) in Theory and Practice", Islam and Christian-Muslim Relations, Vol. 25, No. 1 (Januari 2014), hal. 67-88. 
dipilihnya ${ }^{35}$. Dengan demikian, minoritas muslim justru memiliki sebuah kesempatan untuk tetap menjalankan aqidah yang menjadi ajaran Islam, sekaligus menjadikan perbedaan sebagai sebuah peluang untuk saling berinteraksi dan memahami kesejatian hidup.

\section{F. Penutup}

Penelitian ini merupakan sebuah eksplorasi bagaimana pendidikan di minoritas muslim menjadikan wirausaha sebagai bagian dari pendidikan pesantren. Dengan tujuan utama untuk mendidik santri dalam mendalami pengetahuan agama, maka pesantren menyelenggarakan pendidikan diniyah. Namun sebagai pribadi yang merupakan bagian dari masyarakat, santri-santri pada waktunya akan kembali lagi ke masyarakat. Dengan pandangan ini, maka pihak manajemen pesantren memandang perlu akan wujudnya sebuah program yang dapat membantu santri untuk tetap mandiri dan berusaha dengan kemampuannya sendiri. Maka, pendidikan yang berwawasan kewirausahaan menjadi sebuah pilihan. Adanya pendidikan Islam di wilayah minoritas muslim memberikan kesempatan bagi keluarga muslim untuk memperkuat kapasitas, mempertahankan identitas, dan merawat syariah. Peluang ini sekaligus digunakan untuk menjaga kelangsungan hidup seorang muslim di tengah-tengah kemajemukan masyarakat dengan pelbagai suku, budaya, dan keyakinan.

Pendidikan kewirausahaan dilaksanakan sesuai dengan keadaan lingkungan masing-masing pondok. Secara umum pertanian, perkebunan, dan perikanan menjadi pilihan utama. Secara khusus pula dilaksanakan pengembangan koperasi dan toko, peternakan, dan jual beli. Program-program ini dilaksanakan masing-masing pondok secara berbeda karena menyesuaikan dengan sumber daya yang ada serta perbedaan akses dan minat santri. Begitu juga dengan dukungan tenaga ahli. Berlangsungnya program ini karena diawali secara internal. Dengan mendapatkan dukungan eksternal kemudian keberlanjutan program dapat berjalan dengan baik. Ditambah lagi dengan pendanaan, pendampingan, dan pemasaran yang dilaksanakan oleh dinas dan lembaga pemerintah terkait,

${ }^{35}$ R. Saleem, I. Treasaden, dan B. K. Puri, "Provision of Spiritual and Pastoral Care Facilities in a High-Security Hospital and Their Increased Use by Those of Muslim Compared to Christian Faith", mental Health, Religion, and Culture, Vol. 17, No. 1 (Januari 2014), hal. 94-100. 
sehingga program yang dimulai sebagai sebuah praktik bagi santri untuk belajar berkembang menjadi unit usaha.

Penelitian ini menunjukkan adanya kerjasama antara elemen yang ada di pondok untuk menyukseskan program yang menjadi bagian dari rencana kerja. Walaupun hanya didukung oleh santri, tenaga pengajar, dan pengurus yayasan, sebagian besar dapat terlaksana. Dari kegiatan ini mendukung proses pembelajaran di sekolah formal, dan menjadi berkontribusi sebagai sumber pendanaan untuk kas pesantren. Bagi santri, menjadi sebuah pengalaman yang menempa keterampilan. Walaupun bagi santri merupakan sebuah beban ketika dijalankan pada tahapan awal, tetapi mereka kemudian dapat menunjukkan keterampilan yang diperoleh dari proses pelatihan yang secara langsung diiplementasikan di lapangan. Tidak lagi sekadar teori semata. Adapun jika diperlukan pendalaman materi, itu juga dilaksanakan langsung di lapangan. Dengan demikian, pendidikan keagamaan tetap berlangsung sebagaimana pola yang menjadi tradisi pesantren. Hanya saja, kewirausahaan menjadi sebuah wawasan dan praktik yang dilaksanakan sebagai kelengkapan pembelajaran yang disesuaikan dengan alam Papua Barat yang juga berfungsi sebagai pembekalan untuk santri.

\section{Daftar Pustaka}

Agbaria, Ayman K. dan Mustafa Muhanad. 2014. "The Case Of Palestinian Civil Society In Israel: Islam, Civil Society, and Educational Activism" dalam Critical Studies in Education. Vol. 55, No. 1. 44-57.

Aijuddin, Anas. 2012. Peran Pesantren dalam Mediasi Konflik Keagamaan di Surakarta. Jakarta: Badan Litbang dan Diklat Kementerian Agama RI.

Awan, I. 2013. "Muslim Prisoners, Radicalizations and Rehabilitation in British Prisons" dalam Journal of Muslim Minority Affair. Vol. 33. No. 2. 371-384.

Bawani, Imam. 1993. Tradisionalisme dalam Pendidikan Islam. Surabaya: alIkhlas.

Copeland, Paul dan James, Scott. 2014. "Policy Windows, Ambiguity, and Commission Entreprneurship: Explaining the Relaunch of the European Union's Economic Rfeorm Agenda" dalam Journal of European Public Policy. Vol. 21. No. 1. Januari:1-19.

Dhofier, Zamakhsyari. 1985. Tradisi Pesantren Studi tentang Pandangan Hidup Kiyai. Jakarta: LP3ES.

El Badaoui, Eliane dan Rebiere, Theresa. 2013. "Education, Informality, and Efficiency: A Matching Model for a Developing Economy" dalam Revue d Economie Politique. Vol. 123. No. 3. 423-441. 
Esteva, Fernanda. 2013. "The impact of Conditional Cash Transfer on Public Education Expenditures: A Political Economy Approach" dalam European Journal of Political Economy. Vol. 32. Desember:268-284.

Estevan, Fernanda. 2013. "The Impact of Conditional Cash Transfer on Public Education Expenditures: A Political Economy Approach" dalam European Journal of Political Economy. Vol. 32. Desember:268-284.

Greene, Stuart. 2013. "Mapping Low-Income African American Parents' Roles in Their Children's Education in a Changing Political Economy" dalam Teachers College Board. Vol. 115. No. 10. Oktober.

Hong, Huang-Yo dan Scardamalia, Marlene. 2014. "Community Knowledge Assesment in a Knowledge Building Environment", dalam Computers \& Education. Vol. 71. Februari:279-288.

Huber, Nathalie. 2013. "Science and Higher Education in the Context of Economy and Media" dalam Kolner Zeitschrift Fur Soziologie Und Sozialpsychologie, Vol. 65. No. 4. Desember:734-737.

Iversen, L. L. 2014. "Presenting The Iterative Curriculum Discourse Analysis (ICDA) Approach" dalam British Journal of Religious Education. Vol. 36. No. 1. Januari:53-71.

Jamal, A. dan Shukor, S. A. 2014. "Antecedents and Outcomes of Interpersonal Influences and the Role of Acculturation: The Case of Young BritishMuslims" dalam Journal of Business Research, Vol. 67. No. 3. 237-245.

Lahelma, E; Lappalainen, S; Meitola, R; dan Plamu, T. 2014. "Discussions That 'Tickle Our Brains': Constructing Interpretations Through Multiple Ethnographic Data-Sets" dalam Ethnography and Education. Vol. 9. No. 1. 51-65.

Manring, Susan L. 2014. "The Role of Universities in Developing Interdisciplinary Action Research Collaborations to Understand and Manage Resilient Social-Ecological Systems" dalam Journal of Cleaner Production. Vol. 64. Februari:125-135.

Marginson, Simon. 2014. "Student Self-Formation in International Education", Journal of Studies in International Education, Vol. 18. No. 1. Februari:6-22.

Maussen, M. dan Grillo, R. 2014 "Regulation of Speech in Multicultural Societies: Introduction" dalam Journal of Ethnic and Migration Studies, Vol. 40. No. 2. Februari:174-193.

Medvedeva, E. I. 2013. "The Rsetructuring of Education Under Conditions of the Innovative Development of the Economy" dalam Russian Education and Society. Vol. 55. No. 11. November:84-93.

Pan, Shan L. dan Tan, Barney. 2011. "Demystifyng Case Research: A Structuredpragmatic-situasional (SPS) Approach to Conducting Case Study" dalam Information and Organization. Vol. 21. No. 3. November:161-176.

Ryoo, Kihyun dan Linn, Marcia C. 2014. "Designing Guidance for Interpreting Dynamic Visualizations: Generating Versus Reading Explanations" dalam Journal of Research in Science Teaching. Vol. 51. No. 2. Februari :147-174.

Saleem, R; Treasaden, I; dan Puri, B. K. 2014. "Provision of Spiritual and Pastoral Care Facilities in a High-Security Hospital and Their Increased Use by Those of Muslim Compared to Christian Faith", dalam Mental Health, Religion, and Culture. Vol. 17. No. 1. Januari. 94-100. 
Schneider, Carsten dan Rohlfing, Ingo. 2013. "Combining QCA and Process Tracing in Set-Theoretic Multi-Method Research" dalam Sociological Methods and Research. Vol. 42. No. 4. November:559-597.

Shavit, U. 2014. "Can Muslims befriend Non-Muslims? Debating al-Wala wa alBara (Loyalti and Disavowal) in Theory and Practice" dalam Islam and Christian-Muslim Relations. Vol. 25. No. 1. Januari:67-88.

Sheikh, I; Mohyuddin, A; Chaudry, H-R; dan Iqbal, S. 2014. "Identity and Self Images in Adoscence a Case Study of Bumburet valley in District Chitral Pakistan" dalam World Applied Sciences Journal. Vol. 29. No. 1. 96-105.

Smith, Gregory. A. 2014. "The New Political Economy of Urban Education: Neoliberalism, Race, and the Right to the City" dalam Monthly Review - An Independent Socialist Magazine, Vol. 65. No. 4. 58-63.

So, Kyunghee; Lee, Sangeun; Park, Jiae; dan Kang, Jiyoung. 2014. "The Idea of Cosmopolitan in Korea's National Curriculum" dalam Asia Pacific Journal of Education. Vol. 34. No. 1. Januari:1-14.

Talib, Mohammad. 2013. "The Moral Economy of the Madrasa: Islam and Education Today" dalam Journal of Islamic Studies. Vol. 24. No. 2. 252255.

Wainwright, Lucy dan Nee, Claire. 2014. "The Good Lives Model - New Directions for Preventative Practice With Children?" dalam Psychologhy Crime \& Law. Vol. 20. No. 2. Februari:166-182.

Wekke, Ismail Suardi. 2011. "Pendidikan Islam dan Pemberdayaan Masyarakat (Tinjauan Pendidikan Vokasional Pesantren Roudhotul Khuffadz, Sorong)" dalam Jurnal Kajian Islam Interdisipliner. Vol. 10. No. 1. Desember:23-53.

Wekke, Ismail Suardi. 2012. "Pesantren dan Pengembangan Kurikulum Kewirausahaan: Kajian Pesantren Roudhothul Khuffadz Sorong Papua Barat" dalam Jurnal Penelitian Sosial Keagamaan Inferensi.Vol. 6. No. 2. Desember:205-226.

Wekke, Ismail Suardi. 2012. Pendidikan Agama dan Kewirausahaan Santri: Kajian Pesantren Rodhotul Khuffadz Sorong Papua Barat. Makalah dalam Temu Ilmiah Nasional Psikologi 2012 di Fakultas Psikologi. Universitas Airlangga. 20-21. November:269-291.

Wekke, Ismail Suardi. 2013. "Religious Education and Empowerment: Study on Pesantren in Muslim Minority West Papua" dalam Jurnal Ilmu-ilmu Keislaman Miqot. Vol. XXXVII. No. 2. Juli-Desember:374-395.

Westerman, Michael A. 2014. "Examining Arguments Againts Qualitative Research: Case Study Illustrating the Challenge of Finding a Sound Philosophical Basis for a Human Sciences Approach to Psychology" dalam New Ideas in Psychology. Vol. 32. Januari:42-58.

Ziemek, Manfred. , 1983. Pesantren dalam Perubahan Sosial. Jakarta: P3M 